\title{
Identification of viruses infecting cucurbits and determination of genetic diversity of Cucumber mosaic virus in Lorestan province, Iran
}

\author{
Vahid Hasanvand, Masoud Shams-bakhsh* \\ Plant Pathology Department, Faculty of Agriculture, Tarbiat Modares University, Tehran, Iran
}

Vol. 57, No. 2: 91-100, 2017

DOI: 10.1515/jppr-2017-0012

Received: May 18, 2016

Accepted: April 7, 2017

*Corresponding address:

shamsbakhsh@modares.ac.ir

\begin{abstract}
Various viral pathogens infect Cucurbitaceae and cause economic losses. The aim of the present study was to detect plant viral pathogens including Cucumber mosaic virus (CMV), Cucumber green mottle mosaic virus (CGMMV), Zucchini yellow mosaic virus (ZYMV), Cucurbit yellow stunting disorder virus (CYSDV) and Cucurbit chlorotic yellows virus (CCYV) in Lorestan province, in western Iran, and also to determine CMV genetic diversity in Iranian populations. A total of 569 symptomatic leaf samples were collected in 2013 and 2014 from cucurbits growing regions in Lorestan province. The collected samples were assessed for viral diseases by ELISA. The results showed virus incidences in most regions. Then, the infection of 40 samples to CMV was confirmed by RT-PCR. Moreover, to distinguish between the two groups (I and II) of CMV, PCR products were digested by two restriction enzymes XhoI and EcoRI. Results of the digestion showed that the isolates of Lorestan belonged to group I. The CMV-coat protein gene of eight isolates from different regions and hosts was sequenced and phylogenetic analysis was performed. Subsequent analyses showed even more genetic variation among Lorestan isolates. The phylogenetic tree revealed that Lorestan province isolates belonged to two IA and IB subgroups and could be classified together with East Azerbaijan province isolates. The results of the present study indicate a wide distribution of CMV, ZYMV, CGMMV, CYSDV and CCYV viruses in cucurbits fields of Lorestan province and for the first time subgroup IB of CMV was reported on melon from Iran.
\end{abstract}

Key words: CMV subgroup, genetic diversity, RFLP

\section{Introduction}

The members of the Cucurbitaceae family are among the most important agricultural crops grown in tropical and subtropical regions. The main species of cultivated cucurbits are cucumber (Cucumis sativus), melon (C. melo), watermelon (Citrullus lanatus), and different squash species (Cucurbita pepo, C. moschata, and C. maxima) (Robinson and Decker-Walters 1997). Cucurbits are grown throughout Lorestan province of Iran. Around 35 viruses have been reported on the Cucurbitaceae worldwide (Provvidenti 1996). Some of these viruses which include: Cucumber mosaic virus (CMV), Zucchini yellow mosaic virus (ZYMV), Cucumber green mottle mosaic virus (CGMMV), Cucumber yellow stunting disorder virus (CYSDV) and Cucurbit chlorotic yellows virus (CCYV) have been reported from field-grown cucurbit crops in Iran (Rahimian and Izadpanah 1977; Rahimian and Izadpanah 1978; Ghorbani 1988; Keshavarz and Izadpanah 2005; Bananej et al. 2013; Keshavarz et al. 2013a).

ZYMV is a dangerous virus and it is widely reported in more than 50 countries (Desbiez and Lecoq 1997). CGMMV causes the appearance of mosaic and green or white spots on the leaves and fruit as well as damage to the quality and quantity of fruit. The watermelon strain of CGMMV causes severe disease symptoms in plants, particularly the decline of fruit which results in 
economic losses to watermelon growers (Shim et al. 2005). CYSDV is a destructive cucurbit virus in large areas of the world that reduces the yield from 30 to 50 percent (Louro et al. 2000). This virus has spread in recent years, and has been found in many regions of Iran (Keshavarz et al. 2013b). CCYV is a new whitefly-transmitted crinivirus which causes serious harm to melon and cucumber crops. It causes yield losses in cucumber and a considerable decrease in the sugar content of melons (Gyoutoku et al. 2009).

CMV is one of the members of the genus Cucumovirus in the family Bromoviridae. CMV has three single-stranded plus-sense RNAs, that code for five functional proteins [1a, 2a, 2b, 3a and coat protein (CP)]. Proteins $1 \mathrm{a}$ and $2 \mathrm{a}$, encoded by RNA1 and RNA2, respectively, are essential for replication. Protein $2 \mathrm{~b}$ is expressed from subgenomic RNA 4A, that is derived from RNA2 (Soards et al. 2002). The RNA3 cods for two proteins, movement protein (MP) and coat protein. The CP is translated from the subgenomic RNA4 and is required for encapsidation, systemic infection or long distance movement, aphid transmission and host range (Boccard and Baulcombe 1993). According to serology, nucleic acid hybridization and restriction fragment length polymorphism (RFLP), CMV isolates have been divided into two main groups I and II (Palukaitis and García-Arenal 2003). The members of group I based on phylogenetic analysis have been divided into two subgroups IA and IB. CMV has a broad host range in 85 separate families of dicotyledons and monocotyledons. The virus is transmitted by 80 species of aphids in a non-persistent and non-circulative manner (Palukaitis and García-Arenal 2003).

Although the five mentioned cucurbit viruses have been reported in various regions of Iran no comprehensive study on the existence of these viruses in the western region of Iran has been carried out. Despite extensive cultivation of cucurbits in Lorestan province of Iran, surveys for viral infections and differentiation of viral isolates have not been done. This report summarizes the findings of a survey made during two years (2013 and 2014), in order to identify the viruses infecting cucurbit crops (squash, cucumber and melon) in Lorestan province. Since CMV has been reported in many areas of the country, another objective of this study was to determine CMV subgroups and genetic diversity. The results of this study would be useful for the management of cucurbit virus diseases.

\section{Materials and Methods}

\section{Surveys and sample collection}

Different cucurbit fields in six regions were visited on several occasions in the springs and summers of 2013 and 2014. During these surveys 569 symptomatic leaf samples of cucumber, squash and pumpkin were collected from several locations in Khorramabad, Poledokhtar, Doureye-e-chegini, Alashtar, Koohdasht and Broujerd.

\section{ELISA}

The infectivity of all collected samples were examined by indirect-ELISA (Converse and Martin 1999) using specific polyclonal antisera against CMV, ZYMV, CGMMV, CYSDV and CCYV. The CMV, CYSDV and CCYV (1:300) antisera were obtained from the Plant Virology Research Center (PVRC), Shiraz, Iran. ZYMV $(1: 5,000)$ and CGMMV $(1: 3,000)$ antisera were obtained from DSMZ-Germany. Goat anti-rabbit-IgG alkaline phosphatase conjugate (Promega, USA) was used as a secondary antibody at a $1: 7,500$ dilution. Absorbance was measured using an ELISA reader (Anthos 2.020) at $405 \mathrm{~nm}$. Samples were considered positive if their absorbance was equal to or greater than twice that of healthy control mean values. Each sample was tested in duplicate.

\section{RNA extraction, RT-PCR and sequencing}

Total RNA extraction of the 40 ELISA-positive samples to CMV antibody was performed using the RNX-Plus kit (CinnaGen, Tehran, Iran) according to the manufacturer's instructions.

The RT-PCR was performed using CMVCPf (5'-GCTTCTCCGCGAG-3') and CMVCPr (5'-GCCGTAAGCTGGATGGAC-3') primer pair corresponding to the CP region of CMV (Davies and Symons 1988). The reverse transcription was performed using the hyperScript RT premix kit as described by the manufacturer (GeneAll, South Korea). Approximately 300 ng of total RNA was subjected to hyperScript RT premix for $1 \mathrm{~h}$ at $42^{\circ} \mathrm{C}$ in a $20 \mu \mathrm{l}$ reaction mixture with $20 \mathrm{pmol}$ of the reverse primer. PCR was performed in a $25 \mu \mathrm{l}$ reaction mixture containing $10 \mu \mathrm{l}$ of the reverse transcribed mixture, $2.5 \mu \mathrm{l}$ of 10X PCR buffer, $2 \mathrm{mM} \mathrm{MgCl}_{2}, 2.5 \mathrm{pmol}$ CMVCPr and 1.25 Units Taq DNA polymerase (Fermentas, Lithuania). The RT-PCR reaction was carried out in a SensQuest thermocycler (Germany). After an initial denaturation step at $94^{\circ} \mathrm{C}$ for $4 \mathrm{~min}, 35$ cycles of denaturation at $94^{\circ} \mathrm{C}$ for $30 \mathrm{~s}$, annealing at $50^{\circ} \mathrm{C}$ for $45 \mathrm{~s}$ and extension at $72^{\circ} \mathrm{C}$ for $1 \mathrm{~min}$, followed by a final polymerization at $72^{\circ} \mathrm{C}$ for 5 min were performed. The PCR products were separated on a $1.2 \%$ agarose gel and stained with ethidium bromide $\left(0.5 \mu \mathrm{g} \cdot \mathrm{ml}^{-1}\right)$ to determine the size of the amplicons. Gel electrophoresis of RT-PCR products revealed an expected size amplicon of approximately $866 \mathrm{bp}$. PCR products were gel excised, purified using (GeneAll, South Korea) and sequenced in both directions (Macrogen Inc, Seoul, 
Table 1. Selected isolates abbreviations, accession numbers and origins of Cucumber mosaic virus from Iran and isolates from other countries were obtained from the GenBank database

\begin{tabular}{|c|c|c|c|c|c|c|c|}
\hline Isolates & $\begin{array}{c}\text { Accession } \\
\text { numbers }\end{array}$ & Abbreviation & Host & Isolates & $\begin{array}{l}\text { Accession } \\
\text { numbers }\end{array}$ & Abbreviation & Host \\
\hline TEH_A & JX865605 & ToV29 & $\begin{array}{l}\text { Lycopercicon } \\
\text { esculentum }\end{array}$ & LOR_H & KT279572 & LOR_H & C. sativus \\
\hline TEH_B & JX865604 & ToV11 & L. esculentum & IND_A & EU573928 & Lucknow-SKR & Gladiolus sp. \\
\hline TEH_C & $J X 86560$ & ToV2 & L. esculentum & IND_B & AY754359 & Kerala & Vanilla planifolia \\
\hline TEH_D & JX865598 & CuV & Cucumis sativus & IND_C & GU253913 & - & Ricinus communis \\
\hline TEH_E & JX865597 & CuV4 & C. sativus & IND_D & AJ890465 & - & Lilium tigrinum \\
\hline TEH_F & JX865594 & ChV35 & Chenopodium sp. & IND_E & AJ890464 & - & Oriental lily \\
\hline AZB-A & AY871069 & S337 & C. sativus & IND_F & LN649264 & Palampur & - \\
\hline AZB-B & JX025994 & Jol186 & muskmelon & JAP_A & AF103991 & Pepo & - \\
\hline AZB-C & JX025997 & Mgh91 & muskmelon & JAP_B & AB004781 & D8 & Japanese radish \\
\hline AZB-D & JX025999 & Ajs4 & L. esculentum & JAP_C & D28487 & FT & $\begin{array}{l}\text { L. esculentum } \\
\text { esculentum }\end{array}$ \\
\hline AZB-E & JX025991 & Bon94 & Cucurbita sp. & JAP_D & D28489 & CS & Limonium sinuatum \\
\hline AZB-F & JX025990 & Zdj31 & C. sativus & JAP_E & D28486 & $\mathrm{N}$ & L. sinuatum \\
\hline Kho_A & JX865596 & CuKh54 & C. sativus & JAP_F & AB049568 & $\mathrm{HL}$ & - \\
\hline Kho_B & JX865595 & CuKh16 & C. melo & KOR_A & L36251 & KOR & - \\
\hline Kho_C & KC122254 & ToKR1 & L. esculentum & KOR_B & AJ276481 & MF & - \\
\hline Kho_D & KC122255 & ToKR2 & L. esculentum & KOR_C & KC527770 & RP46 & Capsicum annuum \\
\hline Kho_E & KC122256 & ToKR3 & L. esculentum & KOR_D & KC527769 & RP45 & C. annuum \\
\hline Kho_F & KC122257 & ToKR4 & L. esculentum & KOR_E & L36525 & $A B I$ & Gladiolus \\
\hline ESF_A & KF873620 & Cuk & C. sativus & KOR_F & AF013291 & AS & - \\
\hline ESF_B & KF873618 & Cud & C. sativus & SPA_A & AJ829769 & MAD99/2 & melon \\
\hline ESF_C & KF873617 & Csu & Cucurbita pepo & SPA_B & AJ829770 & MAD99/4 & C. pepo \\
\hline ESF_D & KF873615 & Cues & C. sativus & SPA_C & AJ829771 & MAD96/3 & melon \\
\hline ESF_E & EF620777 & Ld & C. sativus & SPA_D & AJ829772 & MAD93/1 & melon \\
\hline$E_{-} F_{-} E$ & KF873616 & Kryz & Vigna radiata & SPA_E & AJ829773 & MAD01/3 & Diplotaxis erucoides \\
\hline LOR_A & KT279565 & LOR_A & C. sativus & SPA_F & AJ829774 & MAD96/2 & melon \\
\hline LOR_B & KT279566 & LOR_B & C. sativus & USA_A & JF918967 & N1-04 & Vinca minor \\
\hline LOR_C & KT279567 & LOR_C & C. sativus & USA_B & JF918964 & N1-05 & V. minor \\
\hline LOR_D & KT279568 & LOR D & C. sativus & USA_C & JF918966 & N1-03 & V. minor \\
\hline LOR_E & KT279569 & LOR_E & C. sativus & USA_D & GU362669 & - & Mertensia virginica \\
\hline LOR_F & KT279570 & LOR_F & C. melo & USA_E & KJ486271 & CM3 & Mazus reptans \\
\hline LOR_G & KT279571 & LOR_G & Cucurbita sp. & USA_F & AF523351 & CK54 & - \\
\hline
\end{tabular}

South Korea) using an ABI3700 DN sequencer. The accession numbers of the $\mathrm{CP}$ sequence of $\mathrm{CMV}$ deposited in GenBank database and the other $\mathrm{CP}$ sequences obtained from GenBank are shown in table 1.

\section{In silico restriction enzyme analysis}

In silico digestions were performed with the pDRAW32 software, which is useful for generation of virtual agarose gels, predicting a restriction pattern of a sequence (Kield 2006). The sequence of nine isolates chosen for restriction enzyme digestion pattern comparisons and in silico restriction fragment length polymorphism (RFLP) were exported to the pDRAW32 program.

For validation and confirmation of the in silico predicted pattern of restriction enzyme analysis, the RT-PCR amplified fragments were digested by two enzymes: XhoI and EcoRI (Fermentas Inc., Lithuania). The digestions of 38 samples were performed according to the manufacturer's instructions. Approximately $100 \mathrm{ng}$ of each PCR product was digested in 5 units of enzyme and $20 \mu \mathrm{l}$ of $1 \mathrm{X}$ restriction buffer containing 
$100 \mathrm{ng} \cdot \mathrm{ml}^{-1}$ bovine serum albumin (BSA). The reactions were allowed to take place at $37^{\circ} \mathrm{C}$ for $2-3 \mathrm{~h}$, and then analyzed on a $1.5 \%$ agarose gel.

\section{Sequence alignment, estimation of population genetic parameters}

Multiple nucleotide sequence alignments were performed using CLUSTALW implemented in MEGA version 5 software (Tamura et al. 2011). Aligned CMV sequences were assessed using DnaSP version 5.1 (Rozas et al. 2003) and GenAlEx software (Peakall and Smouse 2006). The number of segregation sites (S), Watterson's estimator of $\theta_{\mathrm{w}}$ (Watterson 1975), and $\mathrm{Pi}$ (the average number of nucleotide differences between two random sequences in a population) (Tajima 1983) which is also called genetic diversity were estimated. Haplotype diversity (Hd) was also used to assess selection pressure imposed upon the $\mathrm{CP}$ region of the 62 sequence of CMV isolates (Table 1), non-synonymous [Pi(a), amino-acid altering] and synonymous $[\mathrm{Pi}(\mathrm{s})$, silent] substitution rates and their associated ratios $\mathrm{Pi}(\mathrm{s}) / \mathrm{Pi}(\mathrm{a})$ were estimated.

\section{Recombination analysis}

To detect putative recombinants between the 32 sequences of the Iranian CMV isolates (Table 1), they were aligned and analyzed using RDP3 (Martin et al. 2010). A total of 7 recombination detection methods including RDP, Bootscan, GENECONV, MaxChi, Chimaera, Siscan and 3SEQ were performed.

\section{Phylogenetic analysis}

For reconstructing molecular phylogenetic relationships, the CP gene sequence of each isolate was compared with those of the other isolates available in GenBank using the BLAST homology search program. The selected DNA sequences were aligned by Clustal X2 (http://www.clustal.org//) using the default parameters. The aligned data sets were manually edited in MEGA 5. The model of base substitution was selected using MrModeltest 2 (Posada and Crandall 1998). The Akaike-supported model, a general time reversible model, including among-site rate heterogeneity $(\mathrm{GTR}+\mathrm{G})$ was used in phylogenetic analyses. Bayesian analysis was performed using MrBayes v3.1.2 running the chains for one million generations (Huelsenbeck and Ronquist 2001). After discarding burn-in samples and evaluating convergence, the remaining samples were retained for further analysis. The Markov Chain Monte Carlo (MCMC) method within a Bayesian framework was used to estimate the posterior probabilities of the phylogenetic trees using the 50\% majority rule (Larget and Simon 1999). For phylogenetic analysis of the CP gene, the isolate CMV-Q (accession number M21464) was used as the out-group.

\section{Results}

\section{Incidence and detection of viruses in cucurbit samples}

An analysis of the 352 collected samples in 2013 showed that $30.11 \%$ (106 out of 352 ), $8 \%$ (24 out of 300 ), and $11 \%$ (33 out of 300) of the samples were infected with CMV, ZYMV and CGMMV, respectively. Additionally, $17.92 \%$ of the samples (19 out of 106 ) reacted to the CYSDV-CCYV antisera. However, monitoring of samples in 2014 showed that $22.11 \%$ (48 out of 217 ), $16.4 \%$ (17 out of 104 ), and $9.2 \%$ (20 out of 217 ) of the samples were infected with CMV, ZYMV and CGMMV, respectively. Additionally, $7.6 \%$ of the samples (8 out of 104) reacted to the CYSDV-CCYV antisera. Also 43.07\%, 27.5\%, 26.13\%, 12.5\%, 24.44\%, 15.94\% of the total samples from Khorramabad, Poledokhtar, Doureye-e-chegini, Koohdasht, Borujerd and Alashtar locations in Lorestan province were infected with CMV, respectively.

\section{Mixed infections}

Part of the samples were infected with more than one virus. The following percentages, $3.58 \%$ (7 out of 195), $2.89 \%$ (6 out of 207 ), $2.2 \%$ ( 4 out of 181 ), $2.12 \%$ ( 2 out of 94 ), $1.47 \%$ (1 out of 68 ) and $2.5 \%$ (2 out of 80 ) were simultaneously infected with CMV and ZYMV, CMV and CGMMV, CMV and SYSDV or CCYV, ZYMV and CGMMV, ZYMV and CYSDV or CCYV and CGMMV and SYSDV or CCYV, respectively. Also 1.2\% (3 out of 248) of the samples were infected with CMV, ZYMV and CGMMV.

\section{RT-PCR and RFLP analysis}

The extracted RNA of the ELISA-positive samples to CMV antibody resulted in a clear amplicon of approximately 866 bp using reverse transcription-polymerase chain reaction with the CMVCPf/CMVCPr primer pair. The obtained RFLP pattern of virtual digestion with XhoI and EcoRI of the CP sequences of CMV clearly differentiated the isolates into two distinct groups. Virtual digestion showed that XhoI can potentially separate the CMV samples into two groups, I and II. The XhoI restriction enzyme divided the subgroups IA and IB into two fragments of 664 and 202 bp whereas none of the members of group II were digested. Therefore, XhoI was considered an efficient and suitable enzyme for differentiation of CMV samples into groups I and II. Furthermore, the EcoRI enzyme 


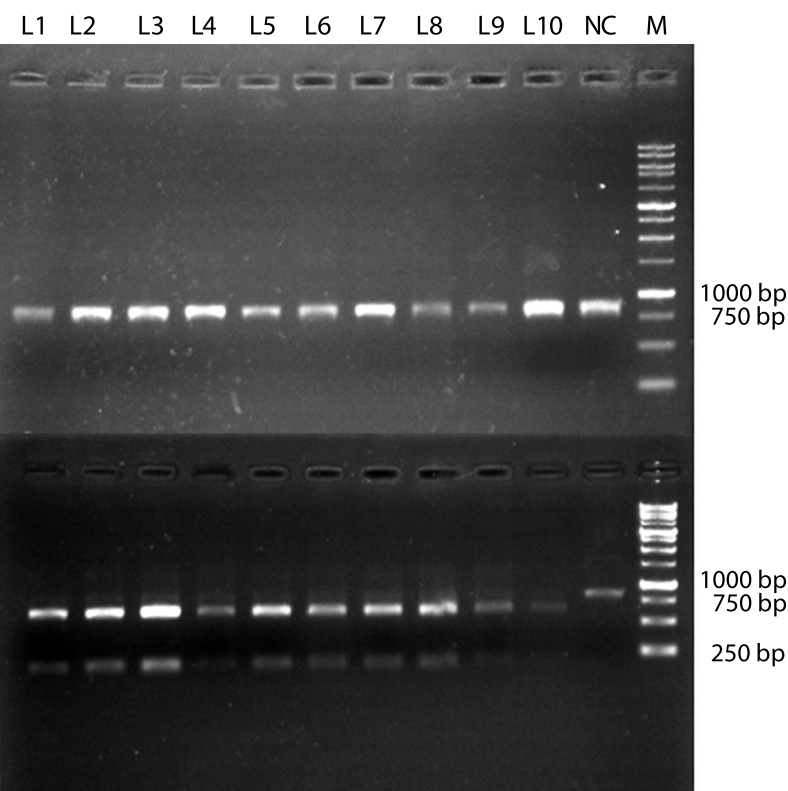

Fig. 1. Electrophoretic pattern of the virus coat protein gene of Cucumber mosaic virus - treated cutting restriction enzymes EcoRI (top) and Xhol (bottom); L1 to L10 - samples; NC - samples that have not been digested by enzyme; $\mathrm{M}$ - GeneRuler ${ }^{\mathrm{TM}} 1 \mathrm{~kb}$ DNA ladder, Fermentas

did not digest subgroups IA and IB whereas it digested members of group II into two parts 704 and $162 \mathrm{bp}$. Therefore, enzymes EcoRI and XhoI confirmed each other's results.

The digestion pattern of our amplified 38 samples showed that they were digested only by the XhoI enzyme, but none were cut by enzyme EcoRI (Fig. 1), so according to the results mentioned it was demonstrated that our samples belonged to group I of CMV. For the first time in the present study, we used the XhoI enzyme for differentiation of CMV samples and we introduced this enzyme as a potential separator of CMV member groups I and II.

\section{Recombination analysis}

The results obtained in the present study indicated that some of the examined strains showed evidence of recombination. However, since the recombination in some strains was supported by less than four RDP3 programs and their $\mathrm{p}$-value was less than $1.0 \times 10^{-6}$, they therefore were considered as 'tentative' recombinants.

\section{Phylogenetic analysis}

The isolates of LORA, LORB, LORD, LORE and LORH were placed in a separate group adjacent to the isolates of subgroup IA. LORA, LORB, LORD, and LORH isolates were placed near Iranian isolates S337 and Jol186 that were respectively reported in Shabestar and Julfa regions, East Azerbaijan province. The LORE isolate was placed adjacent to Mgh91 isolate from Maragheh. It is therefore concluded that Lorestan province isolates were phylogenetically close to East Azerbaijan province isolates. In previous studies, it has been demonstrated that Jol186, S337, E5 and Mgh91 isolates were members of subgroup IA (Bashir et al. 2006; Nematollahi et al. 2012). It is evident that LORA, LORB, LORD, LORE and LORH isolates of Lorestan province can be placed in subgroup IA, while other isolates, including LARC, LORF and LORG belong to a separate group adjacent to subgroup IB isolates. These isolates were more closely related to Iranian Esf172 and Khn1, East Azerbaijan province isolates (Nematollahi et al. 2012). As a result, LORA, LORB, LORD, LORE and LORH isolates of Lorestan province could be placed in subgroup IA (Fig. 2). The sequences reported in this paper were submitted to GenBank and are presented in Table 1.

\section{Genetic diversity of selected CMV isolates}

The population genetic parameters shown in Table 2, were estimated and analyzed. This analysis includes $\pi$, the average pairwise nucleotide difference per site, and $\theta \mathrm{w}$, the mutation rate from segregating number. These estimators were used as two indicators of genetic diversity for the $\mathrm{CP}$ region. Accordingly, Lorestan and Tehran provinces showed the highest and lowest genetic diversity, respectively. Based on the two parameters $W \theta(0.035)$ and $\pi(0.043)$, the genetic diversity of CMV in Lorestan province was the highest. Also according to the same parameters (W $\theta$ and $\pi$ ), Tehran province isolates showed the lowest variation.

\section{Genetic parameters between populations of CMV}

Calculation of genetic variation among CMV populations determined with GenAlEx software revealed that Lorestan and Tehran provinces had the highest and the lowest values of the parameters of population genetics, respectively. Shannon's (Brown and Weir 1983) information index and diversity of Nei (Nei 1978) were 0.198 and 0.135 , respectively for Lorestan, Shannon and Nei parameters were 0.014 and 0.010 for Tehran province. Polymorphism (32.8) amount in Lorestan province was more than other regions of Iran. Generally, the India CMV population (50.54) had the highest rank in polymorphism among the assessed populations.

\section{Variations between populations of CMV}

Based on the analysis of molecular and population variations calculated with GenAlEx software, 186 characters were changed in CMV isolates. Seventy per cent of the variations occurred within a population, and 30\% 


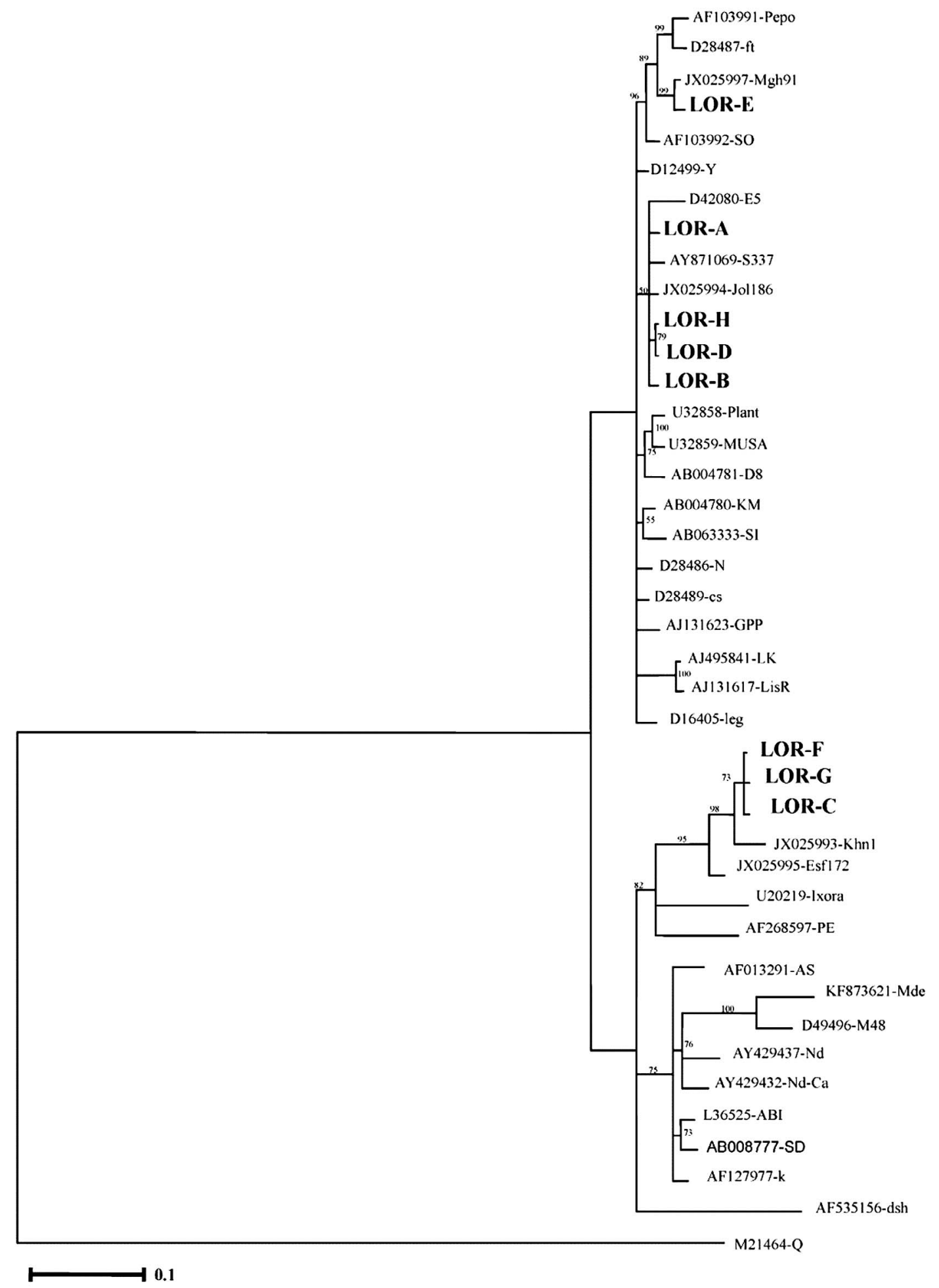

Fig. 2. Bayesian phylogenetic trees of Cucumber mosaic virus isolates based on CP gene including field collected $(n=8)$ and from other regions of the world. The sequence of CMV-Q isolate (Acc. no. M21464) was used as out group. Isolates LORA, LORB, LORD, LORE and LORH in subgroup IA and Isolates LARC, LORF and LORG were placed in IB subgroup

occurred between populations. These values indicate that within a population variation is greater than between variations.

Then, using NTSYSpc software (Rohlf 1998) and by algorithm UPGMA, dendrogram dissimilarity was drawn. The dendrogram revealed that the population of Lorestan province was close to the population from East Azerbaijan province. Also isolates of Isfahan,
Tehran and Khorasan provinces were located near each other according to the dendrogram (Fig. 2).

\section{Selection pressure on the $\mathrm{CP}$ region}

The obtained results showed that the ratio of $\mathrm{Pi}(\mathrm{a}) / \mathrm{Pi}(\mathrm{s})$ for the $\mathrm{CP}$ region of CMV isolates was less than one (Table 2). In regions of the genome where the number 
Table 2. Population parameters estimated based on the coat protein gene of CMV

\begin{tabular}{lccccccccc}
\hline Population & $\begin{array}{c}\text { No. of } \\
\text { sequences }\end{array}$ & $\begin{array}{c}\text { No. of } \\
\text { sites }\end{array}$ & $\mathrm{S}^{\mathrm{a}}$ & $\Theta_{\mathrm{w}}^{\mathrm{b}}$ & $\mathrm{Pi}^{\mathrm{c}}$ & $\mathrm{Hd}^{\mathrm{d}}$ & $\mathrm{Pi}(\mathrm{a})^{\mathrm{e}}$ & $\mathrm{Pi}(\mathrm{s})^{\mathrm{f}}$ & $\mathrm{Pi}(\mathrm{a}) / \mathrm{Pi}(\mathrm{s})$ \\
\hline Lorestan & 8 & 657 & 61 & $0.03581 \pm(0.01589)$ & $0.04376 \pm(0.00672)$ & $0.964 \pm(0.077)$ & 0.01160 & 0.14899 & 0.078 \\
Khorasan & 6 & 657 & 11 & $0.00737 \pm(0.00397)$ & $0.00866 \pm(0.00158)$ & $0.933 \pm(0.122)$ & 0.00794 & 0.01108 & 0.717 \\
Tehran & 6 & 657 & 4 & $0.00267 \pm(0.00172)$ & $0.00345 \pm(0.00055)$ & $0.933 \pm(0.122)$ & 0.00236 & 0.00670 & 0.352 \\
Isfahan & 6 & 657 & 38 & $0.02533 \pm(0.01240)$ & $0.02192 \pm(0.00506)$ & $1.000 \pm(0.096)$ & 0.01726 & 0.03734 & 0.462 \\
East & 6 & 657 & 57 & $0.03800 \pm(0.00503)$ & $0.03907 \pm(0.00927)$ & $1.000 \pm(0.096)$ & 0.01033 & 0.12895 & 0.080 \\
Azerbaijan & & & & & & & & & \\
Japan & 6 & 657 & 50 & $0.03333 \pm(0.01615)$ & $0.03115 \pm(0.00450)$ & $1.000 \pm(0.096)$ & 0.01068 & 0.09637 & 0.111 \\
Korea & 6 & 657 & 69 & $0.04600 \pm(0.00554)$ & $0.04820 \pm(0.00850)$ & $1.000 \pm(0.096)$ & 0.01720 & 0.15071 & 0.114 \\
India & 6 & 657 & 93 & $0.06209 \pm(0.02962)$ & $0.06362 \pm(0.01314)$ & $1.000 \pm(0.096)$ & 0.01550 & 0.13812 & 0.112 \\
USA & 6 & 657 & 86 & $0.05733 \pm(0.02739)$ & $0.05530 \pm(0.01546)$ & $1.000 \pm(0.096)$ & 0.02179 & 0.17110 & 0.127 \\
Spain & 6 & 657 & 10 & $0.00667 \pm(0.00211)$ & $0.00578 \pm(0.00118)$ & $1.000 \pm(0.096)$ & 0.00069 & 0.01705 & 0.041 \\
\hline
\end{tabular}

${ }^{a}$ number of segregating sites

${ }^{b}$ the mutation rate from segregating number

' the average number of nucleotide differences between two random sequences in a population

${ }^{\mathrm{d}}$ haplotype diversity

e the average number of non-synonymous substitutions per non-synonymous sites

${ }^{f}$ the average number of synonymous substitutions per synonymous sites

of synonymous substitutions was more than nonsynonymous substitutions, the type of mutations were neutral and amino acid did not change (purifying selection).

\section{Discussion}

Investigation of incidence of CMV, ZYMV, CGMMV, CYSDV and CCYV in cucurbit growing regions of Lorestan province by ELISA showed that cucurbit plants were infected with all five tested viruses. The obtained results of the present study agree with other reports from Iran which showed that these viruses were present in most growing cucurbit areas of Iran (Bananej and Vahdat 2008). The symptoms of the virus are hidden in hot weather. Therefore spring and autumn, when it is cool, are suitable seasons for sampling. In the spring, the symptoms are easily observable (Valkonen et al. 1992).

Determination of the CMV subgroup is important for epidemiological studies and the determination of genetic diversity is an effective step in virus management (Lin et al. 2003). In this study, CMV subgroups were determined by RFLF and nucleotide sequencing. Therefore, XhoI and EcoRI were applied to diagnose subgroups. In in silico analysis, we found that group I (IA and IB) was digested by XhoI restriction enzyme and resulted in two fragments of 664 and $202 \mathrm{bp}$, while it was not digested by EcoRI. In contrast, members of group II were digested into two fragments, 704 and 162 bp, by EcoRI. Therefore, these two enzymes were able to distinguish the two groups I (IA and IB) and II of CMV. According to virtual digestion, all isolates of Lorestan province were digested into two fragments of 664 and 202 bp by the enzyme XhoI, but were not cut by the enzyme EcoRI and revealed that the isolates of Lorestan province belonged to subgroup I. We recommend the two enzymes, EcoRI and XhoI for diagnosis of subgroups and confirmed it by our experimental results. Use of these enzymes is a fast procedure for distinguishing CMV subgroups.

Considering the overall results of the experimental and enzymatic digestion, one can conclude that all investigated CMV isolates belonged to group I, and that group II was not detected in cucurbit growing regions in Lorestan province. In general, the group I isolates of CMV are more dispersed than isolates of group II (Crescenzi et al. 1993). It has been shown that $80 \%$ of the known isolates belong to subgroup I and the frequency of subgroup IA is more than that of IB (Gallitelli 2000). Group II is more common in cold climates (Roossinck 2002) and since Iran is a subtropical country, it was expected that more Iranian isolates would belong to group I, although group II has been reported from Iran (Bashir et al. 2006; Sokhandan et al. 2007; Rasoulpour and Izadpanah 2008; Nematollahi et al. 2012). In our research, we detected IB subgroup strains from melon in Iran for the first time.

Phylogenetic study showed that five isolates (LORA, LORB, LORD, LORE and LORH) were more closely related to isolates Mgh91, S337, E5 and Jol186. Mgh91 and Jol186 isolates were placed in subgroup IA by Nematollahi et al. (2012) in their study to assess CP and MP genes, and draw a phylogenetic tree. LORA, LORB, LORD, LORE and LORH were placed in 
subgroup IA close to S337 and E5 isolates (Bashir et al. 2006). Khn1 and Esf172 isolates from East Azerbaijan province of Iran, by assessing CP and MP genes, were placed in subgroup IB and LARC, LORF and LORG isolates in our research were grouped with Khn1 and Esf172 isolates (Nematollahi et al. 2012). According to the phylogenetic analysis it could be concluded that isolates from Lorestan province (in western Iran) and East Azerbaijan province (in northwestern Iran) have a high phylogenetic similarity and may have the same origin.

Also, the results of the present study showed that there were more IA subgroups than IB. Isolates of subgroup IB are more common in East Asian countries such as India, China, Philippines and Indonesia (Pratap et al. 2012). This indicates that these isolates are more likely to have originated from East Asia.

The observed variation in Lorestan isolates is not unexpected since the sequenced samples were collected from different regions of Lorestan province where there are very different climates due to its vast geographical expanse. Poldokhtar, in the south of Lorestan, has a tropical climate, with a mean annual temperature of $29.8^{\circ} \mathrm{C}$. Boroujerd, located in the northern part of the province, has cooler weather with a mean annual temperature of $21.1^{\circ} \mathrm{C}$ (Anonymous 2011). Tehran samples were collected from areas with similar climate and most likely the Tehran isolates were derived from one source. Calculation of genetic variation among populations by GenAlEx software, revealed that climatic variation and distance between sampling regions could explain the results. Therefore, it would be expected that the genetic variation in Lorestan would be significantly higher than in other provinces.

CMV has a wide host range and different strains of CMV have been reported from over 1,300 host plants belonging to 500 genera (Palukaitis and García-Arenal 2003). The virus diversity cannot be attributed to the effects of hosting as has been demonstrated in previous research from USA and China (Liu et al. 2009; Nouri et al. 2014). Our results also showed that host differences cannot be attributed to the genetic diversity.

Since observed variation among Iranian CMV population was $30 \%$, it could be concluded that genetic differences of populations reflect their geographic origin. The differentiated population group in this study belonged to a particular geographic area. According to molecular variance and population variations in $\mathrm{CMV}$, it is probable that the observed variation among populations is due to a combination of some processes similar to mutation, recombination and assortment of genome segments.

The ratio values determined for the $\mathrm{CP}$ region by DnaSP software showed that the CP region has purifying selection. In other words, the below one $\mathrm{Pi}(\mathrm{a}) / \mathrm{Pi}(\mathrm{s})$ ratio indicates negative selection to preserve the genome of this region and the nature of the proteins encoded by CP gene is preserved and cannot be changed. Negative selection can reduce genetic variation in a population of viruses and increase the maintenance of coat protein stability. Negative selection of CMV coat protein abundance has been reported in previous studies (Liu et al. 2009; Nouri et al. 2014).

According to the dendrogram of dissimilarity matrix, isolates of Isfahan, Tehran and Khorasan were located in the same cluster. Based on the dendrogram, these isolates have genetic similarity and belong to subgroup IA. Therefore high genetic correlation is reflected among these isolates. Also according to the position of isolates on the dendrogram, it is implied that the population of East Azerbaijan and Lorestan provinces were correlated to East Asian countries such as Korea, Japan and India. Since the subgroup IB isolates are more frequent in East Asia and subgroup IB was detected in two provinces (East Azerbaijan and Lorestan), these results are expected and most likely represent the common origin of the isolates.

In conclusion, the present study showed a wide distribution of CMV, ZYMV, CGMMV, CYSDV and CCYV in cucurbits fields of Lorestan province and genetic diversity of CMV in Iran for the first time. In addition, this is the first report of subgroup IB on melon from Iran. Finally, considering the spread of CMV in Iran, in order to better understand the population genetic structure, the genome of CMV isolates from other regions of Iran should be sequenced.

\section{References}

Anonymous. 2011. Meteorological Department. Lorestan Province. Iran. http://www.lorestanmet.ir

Bananej K., Menzel W., Kianfar N., Vahdat A., Winter S. 2013. First report of Cucurbit chlorotic yellows virus infecting cucumber, melon, and squash in Iran. Plant Disease 97 (7): 1005. DOI: 10.1094/pdis-01-13-0125-pdn

Bananej K., Vahdat A. 2008. Identification, distribution and incidence of viruses in field-grown cucurbit crops of Iran. Phytopathologia Mediterranea 47: 247-257.

Bashir N.S., Kalhor M.R., Zarghani S.N. 2006. Detection, differentiation and phylogenetic analysis of Cucumber mosaic virus isolates from cucurbits in the northwest region of Iran. Virus Genes 32 (3): 277-288. DOI: 10.1007/s11262-005$-6912-2$

Boccard F., Baulcombe D. 1993. Mutational analysis of cis-acting sequences and gene function in RNA3 of Cucumber mosaic virus. Virology 193 (2): 563-578. DOI: 10.1006/ viro.1993.1165

Brown H.D., Weir B.S. 1983. Measuring genetic variability in plant populations. p. 219-239. In: "Isozymes in Plant Genetics and Breeding" (S.D. Tanksley, T.J. Orton, eds.). Part A. Elsevier Sciense Publishers, Amsterdam, 527 pp.

Converse R.H., Martin R.R. 1999. ELISA methods for plant viruses. p. 179-196. In: "Serological Methods for Detection and Identification of Viral and Bacterial Plant Pathogens, A Laboratory Manual" (R. Hampton, E.M. Ball, S.H. De Boer, eds.). APS Press, St. Paul, MN, 389 pp. 
Crescenzi A., Barbarossa L., Gallitelli D., Martelli G. 1993. Cucumber mosaic cucumovirus populations in Italy under natural epidemic conditions and after a satellite-mediated protection test. Plant Disease 77 (1): 28-33. DOI: 10.1094/ pd-77-0028

Davies C., Symons R.H. 1988. Further implications for the evolutionary relationships between tripartite plant viruses based on Cucumber mosaic virus RNA 3. Virology 165 (1): 216-224. doi.org/10.1016/0042-6822(88)90675-7

Desbiez C., Lecoq H. 1997. Zucchini yellow mosaic virus. Plant Pathology 46 (6): 809-829. DOI: 10.1046/j.1365-3059.1997. d01-87.x

Francki R.I.B. 1988. Cucumber green mottle mosaic tobamovirus. In: "Plant Viruses Online: Descriptions and Lists from the VIDE Database" (A.A. Brunt, K. Crabtree, M.J. Dallwitz, A.J. Gibbs, L. Watson E.J. Zurcher, eds.). Version: 16th January 1997. http://biology.anu.edu.au/Groups/MES/vide/

Gallitelli D. 2000. The ecology of Cucumber mosaic virus and sustainable agriculture. Virus Ressearch 71 (1-2): 9-21. DOI 10.1016/s0168-1702(00)00184-2

Ghorbani S. 1988. Isolation of Zucchini yellow mosaic virus in the Tehran province. Iranian Journal of Plant Pathology 24: $13-15$.

Gyoutoku Y., Okazaki S., Furuta A., Etoh T., Mizobe M., Kuno K., Hayashida S., Okuda M. 2009. Chlorotic yellows disease of melon caused by Cucurbit chlorotic yellows virus, a new crinivirus. Japanise Journal of Phytopathology 75 (2): 109 -111. DOI: 10.3186/jjphytopath.75.109

Huelsenbeck J.P., Ronquist F. 2001. MRBAYES: Bayesian inference of phylogenetic trees. Bioinformatics 17 (8): 754-755. doi.org/10.1093/bioinformatics/17.8.754

Kaper J.M., Waterworth H.C. 1981. Cucumoviruses. p. 257-332. In: "Handbook of Plant Virus Infections: Comparative Diagnosis" (E. Kurstak, ed.). Elsevier/North-Holland Biomedical Press, Amsterdam, The Netherlands, 943 pp.

Keshavarz T., Izadpanah K. 2005. Etiology of cucurbit yellows in the Boushehr province, Iranian Journal of Plant Pathology 41 (2): 291-292.

Keshavarz T., Shams-Bakhsh M., Izadpanah K., Malboobi M.A. 2013a. Occurrence and genome analysis of Cucurbit chlorotic yellows virus in Iran. Journal of Phytopathology 162 (7-8): 523-526. DOI: 10.1111/jph.12212

Keshavarz T., Shams-Bakhsh M., Izadpanah K., Nassaj S. 2013b. Geographic distribution and phylogenetic analysis of $\mathrm{Cu}$ curbit yellow stunting disorder virus in Iran. Acta Virologica 57 (4): 415-420. DOI: 10.4149/av_2013_04_415

Kield O. 2006. PDRAW32 1.1. 92 DNA analysis software. AcaClone software. http://www. acaclone.com.

Larget B., Simon D.L. 1999. Markov Chain Monte Carlo algorithms for the Bayesian analysis of phylogenetic trees. Molecular Biology and Evolution 16 (6): 750-759. doi. org/10.1093/oxfordjournals.molbev.a026160

Lin H-X., Rubio L., Smythe A., Jiminez M., Falk B.W. 2003. Genetic diversity and biological variation among California isolates of Cucumber mosaic virus. Journal of General Virology 84: 249-258. DOI: 10.1099/vir.0.18673-0

Liu Y.Y., Yu S., Lan Y.F., Zhang C.L., Hou S.S., Li X.D., Zhang G.M., Shi C.K. 2009. Molecular variability of five Cucumber mosaic virus isolates from China. Acta Virologica 53 (2): 89-97. DOI: 10.4149/av_2009_02_89

Louro D., Vicente M., Vaira A., Accotto G., Nolasco G. 2000. Cucurbit yellow stunting disorder virus (genus Crinivirus) associated with the yellowing disease of cucurbit crops in Portugal. Plant Disease 84 (10): 1156. DOI: 10.1094/PDIS. 2000.84.10.1156A

Martin D.P., Lemey P., Lott M., Moulton V., Posada D., Lefeuvre P. 2010. RDP3: a flexible and fast computer program for analyzing recombination. Bioinformatics 26 (19): 2462-2463. DOI: 10.1093/bioinformatics/btq467

Nei M. 1978. Estimation of Average Heterozygosity and Genetic Distance from a Small Number of Individuals. Genetics 89 (3): 583-590.
Nematollahi S., Sokhandan-Bashir N., Rakhshandehroo F., Zamanizadeh H.R. 2012. Phylogenetic analysis of new isolates of Cucumber mosaic virus from Iran on the basis of different genomic regions. The Plant Pathology Journal 28 (4): 381-389. doi.org/10.5423/ppj.oa.06.2012.0077

Nouri S., Arevalo R., Falk B.W., Groves R.L. 2014. Genetic structure and molecular variability of Cucumber mosaic virus isolates in the United States. PLoS ONE 9 (5): e96582. doi.org/10.1371/journal.pone.0096582

Palukaitis P., García-Arenal F. 2003. Cucumoviruses. Advances in Virus Research 62: 241-323. dx.doi.org/10.1016/S0065-3527(03)62005-1

Peakall R., Smouse P.E. 2006. GENALEX 6: genetic analysis in Excel. Population genetic software for teaching and research. Molecular Ecology Resources 6 (1): 288-295. doi. org/10.1111/j.1471-8286.2005.01155.x

Posada D., Crandall K.A. 1998. Modeltest: testing the model of DNA substitution. Bioinformatics 14 (9): 817-818. doi. org/10.1093/bioinformatics/14.9.817

Pratap D., Kumar S., Snehi S., Raj S. 2012. Biological and molecular characterization of Cucumber mosaic virus isolate causing shoestring disease of tomato in India which has closer affinity to European or East Asian isolates of CMV. Indian Journal of Virology 23 (1): 57-63. doi.org/10.1007/ s13337-012-0059-2

Provvidenti R. 1996. Diseases caused by viruses. p. 37-45. In: "Compendium of Cucurbit Diseases" (T.A. Zitte, D.L. Hopkins, C.E. Thomas, eds.). American Phytopathological Society, $87 \mathrm{pp}$.

Purcifull D., Hiebert E., Edwardson J. 1984. Watermelon mosaic virus 2. CMI/AAB Descriptions of Plant Viruses. No 293 Preveza, Greece, 115. Commonwealth Mycological Institute and Association of Applied Biologists, Kew, England, UK.

Rahimian H., Izadpanah K. 1977. A new strain of Cucumber green mottle mosaic virus from Iran. Iranian Journal of Agriculture Research 5: 25-34.

Rahimian H., Izadpanah K. 1978. Identity and prevalence of mosaic-inducing cucurbit viruses in Shiraz, Iran. Journal of Phytopathology 92 (4): 305-312. doi.org/10.1111/j.1439-0434.1978.tb03620.x

Rasoulpour R., Izadpanah K. 2008. Properties and taxonomic position of hoary cress strain of Cucumber mosaic virus. Journal of Plant Pathology 90 (1): 97-102.

Robinson R.W., Decker-Walters D.S. 1997. Cucurbits. CAB international, $226 \mathrm{pp}$.

Rohlf F. 1998. NTSYS-pc version 2.0. Numerical Taxonomy and Multivariate Analysis System. Exeter software, Setauket, New York. 44 pp.

Roossinck M.J. 2002. Evolutionary history of Cucumber mosaic virus deduced by phylogenetic analyses. Journal of Virology 76 (7): 3382-3387. doi.org/10.1128/jvi.76.7.3382$-3387.2002$

Rozas J., Sánchez-DelBarrio J.C., Messeguer X., Rozas R. 2003. DnaSP: DNA polymorphism analyses by the coalescent and other methods. Bioinformatics 19 (18): 2496-2497. doi. org/10.1093/bioinformatics/btg359

Shim C.K., Han K.S., Lee J.H., Bae D.W., Kim D.K., Kim H.K. 2005. Isolation and characterization of watermelon isolate of Cucumber green mottle mosaic virus (CGMMV-HY1) from watermelon plants with severe mottle mosaic symptoms. The Plant Pathology Journal 21 (2): 167-171. doi. org/10.5423/ppj.2005.21.2.167

Soards A.J., Murphy A.M., Palukaitis P., Carr J.P. 2002. Virulence and differential local and systemic spread of Cucumber mosaic virus in tobacco are affected by the CMV $2 \mathrm{~b}$ protein. Molecular Plant-Microbe Interactions 15 (7): 647-653. doi.org/10.1094/mpmi.2002.15.7.647

Sokhandan B.N., Nematollahi S., Torabi E. 2007. Cucumber mosaic virus subgroup IA frequently occurs in the northwest Iran. Acta Virologica 52 (4): 237-242.

Tajima F., 1983. Evolutionary Relationship of DNA Sequences in Finite Populations. Genetics 105 (2): 437-460. 
Tamura K., Peterson D., Peterson N., Stecher G., Nei M., Kumar S. 2011. MEGA5: molecular evolutionary genetics analysis using maximum likelihood, evolutionary distance, and maximum parsimony methods. Molecular Biology and Evolution 28 (10): 2731-2739. DOI: 10.1093/molbev/msr121

Valkonen J., Pehu E., Watanabe K. 1992. Symptom expression and seed transmission of Alfalfa mosaic virus and Potato yellowing virus (SB-22) in Solanum brevidens and S. etuberosum. Potato Research 35 (4): 403-410. DOI: 10.1007/ bf02357596

Watterson G.A. 1975. On the number of segregating sites in genetical models without recombination. Theoretical Population Biology 7 (2): 256-276. DOI: 10.1016/0040-5809(75)90020-9 